\title{
Diabetes and Endocrinology
}

\section{Changing Our Concept of Type 2 Diabetes}

\author{
Yoshifumi Saisho, MD, PhD* \\ Department of Internal Medicine, Keio University School of Medicine, Tokyo, Japan
}

$\mathrm{n}$ n contrast to type 1 diabetes (T1D), type 2 diabetes (T2D) is characterized by obesity, insulin resistance, and hyperinsulinemia. Although the amount of insulin secretion is an obvious distinction between T1D and T2D, "hyperinsulinemia" is often overinterpreted in patients with T2D.

There are two things to be considered while evaluating plasma insulin level. The first thing is the effect of hyperglycemia. Glucose is a major driver of insulin secretion by beta cells. Thus, hyperinsulinemia in patients with T2D is often overestimated because of the presence of hyperglycemia. When plasma glucose level is controlled at the same level, the loss of insulin secretion in patients with T2D, compared with non-diabetic individuals, becomes apparent [1].

The second thing is the effect of insulin sensitivity. When insulin sensitivity is reduced, insulin secretion increases in order to maintain normoglycemia. The disposition index, which is insulin secretory capacity adjusted by insulin sensitivity, therefore reflects "true" beta cell function [2]. A reduced disposition index has been consistently shown in patients with T2D. These findings indicate that beta cell function is impaired in patients with T2D, even if "pseudo" hyperinsulinemia is observed in these patients.

Loss of beta cell function in T2D is further evidenced by the loss of beta cell mass. Not only beta cell function, but beta cell mass, i.e., the number of beta cells, has also been shown to decrease in patients with T2D $[3,4]$. Thus, hyperinsulinemia in patients with T2D does not necessarily mean even "normal" beta cell mass. In this regard, we now know that deficit of beta cells is a common pathological feature of both T1D and T2D. Diabetes never develops unless beta cells are impaired.

So, what is the distinction between T1D and T2D? This should be the cause of the beta cell deficit. While the autoimmune attack of beta cells is the cause of T1D, obesity/insulin resistance or, more precisely, weight (visceral fat) gain/reduced insulin sensitivity is likely to be the cause of beta cell deficit in T2D (Figure 1).

This change in the concept of $\mathrm{T} 2 \mathrm{D}$ emphasizes the importance of preservation/protection of residual beta cells as a treatment strategy for T2D. Also, at the same time, it emphasizes that the elimination of the cause of T2D, i.e., obesity and insulin resistance, is significant to prevent further loss of beta cells. Recent studies have shown that reducing beta cell workload by treatment with energy restriction or insulin sensitizers results in better preservation of beta cell function $[5,6]$.

*Correspondence: Yoshifumi Saisho, MD, PhD

Department of Internal Medicine, Keio University School of Medicine, Tokyo, 160 8582, Japan.

E-mail: ysaisho@keio.jp

Received: August 5, 2017; Accepted: September 1, 2017; Published: September 4, 2017

Diabetes and Endocrinology. 2017;1(1):2

DOI: $10.24983 /$ scitemed.de.2017.00030

Copyright (c) 2017 The Author. This is an open-access article distributed under the terms of the Creative Commons Attribution 4.0 International License (CC-BY).
Past

$$
\begin{gathered}
\text { Type } 1 \text { diabetes } \\
\text { Beta cell destruction } \\
\text { Beta cell mass } \downarrow \downarrow \\
\text { Insulin secretion } \downarrow \downarrow
\end{gathered}
$$

Present

\section{Type 1 diabetes \\ Beta cell destruction \\ Beta cell mass $\downarrow \downarrow$ \\ Insulin secretion $\downarrow \downarrow$}

\section{Causes Autoimmune}

\author{
Type 2 diabetes \\ Obesity \\ Insulin resistance \\ Hyperinsulinemia
}

Figure 1. Changing concepts of pathogenesis of type 1 and type 2 diabetes in the past and present.

\section{Type 2 diabetes \\ Beta cell loss \\ Beta cell mass $\downarrow$ \\ Insulin secretion $\downarrow$ \\ Insulin resistance Beta cell overwork}

Therefore, although T2D is characterized by insulin resistance and beta cell dysfunction, it is important to recognize that these two factors are not independently present, but rather act mutually (Figure 2). Therapy for insulin resistance is important not only for those with high insulin resistance, but also to preserve functional beta cell mass in T2D patients with any degree of obesity whose beta cells are already impaired.

This paradigm shift in the concept of T2D also emphasizes the importance of prevention of beta cell loss even before the onset of T2D. Prevention and treatment of obesity/insulin resistance are therefore encouraged in the general population before the onset of diabetes, especially in those with a family history of diabetes and/or prediabetes.

This new concept of T2D also suggests the possibility that "true" hyperinsulinemia may be present before the onset of diabetes when beta cells can sufficiently compensate for reduced insulin sensitivity. The risk of cardiovascular morbidity and mortality is already increased in those with pre-diabetes $[7,9]$, suggesting that atherosclerosis worsens mainly due to "true" hyperinsulinemia before the onset of diabetes. If so, improvement of cardiovascular outcomes in patients with T2D may require treatment of "true" hyperinsulinemia before the onset of diabetes. Recent studies have shown that glucose-lowering therapy has only modest effects to improve cardiovascular outcomes in patients with T2D [10,11]. Therefore, we may need to focus on further preemptive treatments to improve cardiovascular outcomes.

Now, we may need to change our current concept of T2D. This paradigm shift in T2D may contribute to the reinforcement of new research questions and further improvement of diabetes care in clinical practice. 
Past

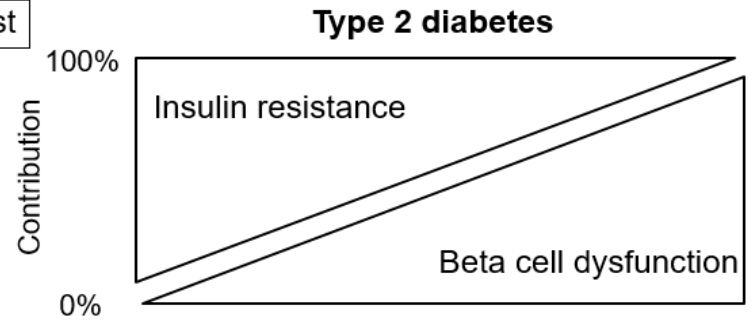

"Insulin resistance versus beta cell dysfunction"

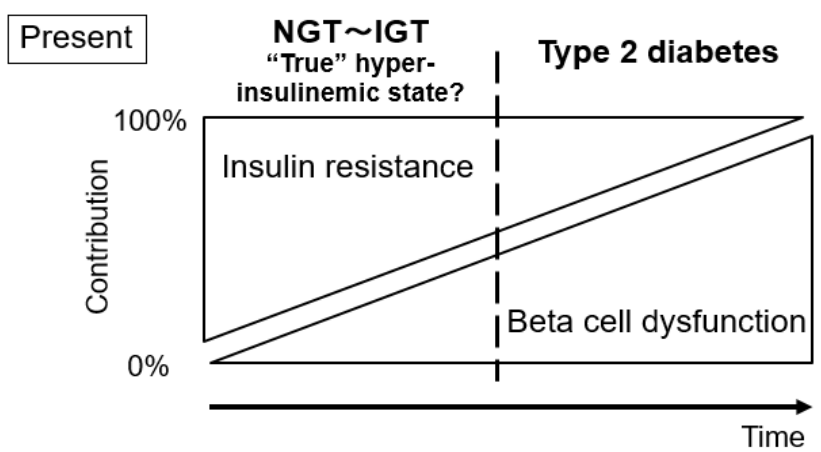

"Beta cell dysfunction due to insulin resistance"

Figure 2. New concept of relative contributions of insulin resistance and beta cell dysfunction in type 2 diabetes (T2D). T2D never develops without beta cell dysfunction. This new concept indicates the need for beta cell protection before the onset of T2D. NGT, normal glucose tolerance; IGT, impaired glucose tolerance.

\section{Article Information}

Conflict of Interest Disclosures: None

Funding: None

\section{Keywords}

Type 2 diabetes; prevention; beta cell.

\section{Abbreviations}

T1D, type 1 diabetes; T2D, type 2 diabetes; NGT, normal glucose tolerance; IGT, impaired glucose tolerance.

\section{References}

1. Lim EL, Hollingsworth KG, Aribisala BS, Chen MJ, Mathers JC, Taylor R: Reversal of type 2 diabetes: normalisation of beta cell function in association with decreased pancreas and liver triacylglycerol. Diabetologia. 2011; 54: 2506-2514.

2. Bergman RN, Ader M, Huecking K, Van Citters G. Accurate assessment of beta-cell function: the hyperbolic correction. Diabetes. 2002; 51 Suppl 1:S212-220.

3. Butler AE, Janson J, Bonner-Weir S, Ritzel R, Rizza RA, et al. Beta-cell deficit and increased beta-cell apoptosis in humans with type 2 diabetes. Diabetes. 2003; 52: 102-110.

4. Inaishi J, Saisho Y, Sato S, Kou K, Murakami R, et al. Effects of obesity and diabetes on alpha- and beta-cell mass in surgically resected human pancreas. The Journal of Clinical Endocrinology and Metabolism. 2016; 101: 2874-2882.

5. Steven S, Hollingsworth KG, Al-Mrabeh A, Avery L, Aribisala B, et al. Very low-calorie diet and 6 months of weight stability in type 2 diabetes: Pathophysiological changes in responders and nonresponders. Diabetes Care. 2016; 39: 808-815.

6. Kahn SE, Haffner SM, Heise MA, Herman WH, Holman RR, et al. Glycemic durability of rosiglitazone, metformin, or glyburide monotherapy. New England Journal of Medicine. 2006; 355: 2427-2443.

7. Tominaga $\mathrm{M}$, Eguchi $\mathrm{H}$, Manaka $\mathrm{H}$, Igarashi $\mathrm{K}$, Kato $\mathrm{T}$, et al. Impaired glucose tolerance is a risk factor for cardiovascular disease, but not impaired fasting glucose. The Funagata Diabetes Study. Diabetes Care; 1999. 22: 920-924.

8. Fujishima M, Kiyohara Y, Kato I, Ohmura T, Iwamoto H, et al. Diabetes and cardiovascular disease in a prospective population survey in Japan: The Hisayama Study. Diabetes. 1996; 45 Suppl 3: S14-16.

9. Huang Y, Cai X, Mai W, Li M, Hu Y. Association between prediabetes and risk of cardiovascular disease and all cause mortality: systematic review and meta-analysis. BMJ. 2016; 355: 15953.

10. Hemmingsen B, Lund SS, Gluud C, Vaag A, Almdal T, et al. Intensive glycaemic control for patients with type 2 diabetes: systematic review with meta-analysis and trial sequential analysis of randomised clinical trials. BMJ. 2011; 343: d6898.

11. Boussageon R, Bejan-Angoulvant T, Saadatian-Elahi M, Lafont S, Bergeonneau $C$, et al. Effect of intensive glucose lowering treatment on all cause mortality, cardiovascular death, and microvascular events in type 2 diabetes: meta-analysis of randomised controlled trials. BMJ. 2011; 343: d4169. 